\title{
Forest condition and chemical characteristics of atmospheric depositions: research and monitoring network in Lombardy
}

\author{
Raffaella BALESTRINI*, Antonio TAGLIAFERRI ${ }^{1)}$, Gianni TARTARI and Flaminio DI GIROLAMO ${ }^{1)}$ \\ CNR-IRSA Water Research Institute, Via della Mornera 25, 20047 Brugherio (MI), Italy \\ ${ }^{1)}$ Regional Forestry Board of Lombardy (ARF), Via Ponchielli 2/4, 20129 Milano, Italy \\ e-mail corresponding author: balestrini@irsa.rm.cnr.it
}

\begin{abstract}
Since 1987, the Regional Forestry Board of Lombardy and the Water Research Institute of the National Research Council have been carrying out surveys of forest conditions and the response of the ecosystem to environmental factors. The study approach is based on a large number of permanent plots for extensive monitoring (Level 1). At this level, crown condition is assessed annually, and soil condition and the nutritional status of forests surveyed. Some of the permanent plots were selected for intensive monitoring (Level 2), focussing mainly on the impact of atmospheric pollution on forest ecosystems. Level 2 monitoring also includes increment analyses, ground vegetation assessment, atmospheric deposition, soil solution analyses and climatic observations. This paper summarises the main results of a pluriannual research, which provides a general picture of the state of forest health in the region and focuses on more detailed investigations, described as case studies. Modified wet and dry samplers which use a water surface to collect dry deposition were used in a pluriannual field campaign at five sites in alpine and prealpine areas, to measure the total atmospheric depositions and to evaluate the nitrogen and sulphate exceedances of critical loads. Throughfall and bulk precipitation chemistry were studied for five years (June 1994-May 1999) at two high elevation forest sites (Val Gerola and Val Masino) which were known to differ in terms of tree health, as assessed by live crown condition. Results indicated a higher contribution from the dry deposition of $\mathrm{N}_{-} \mathrm{NO}_{3}{ }^{-}, \mathrm{N}-\mathrm{NH}_{4}^{+}$and $\mathrm{H}^{+}$and considerable canopy leaching of $\mathrm{Ca}^{2+}, \mathrm{K}^{+}$and weak organic acids at Val Gerola, where the symptoms of damage were more evident. In the area of Val Masino (SO), included since 1997 in the national CONECOFOR network, investigations focused on the effectiveness of the biological compartment in modifying fluxes of atmospheric elements, and on the role of nitrogen both as an acidifying element and as a nutrient. To estimate the input-output budget of the catchment, monitoring was extended to stream water and soil solution.
\end{abstract}

Key words: transparency, injury classes, dry deposition, budget, nutrient nitrogen, critical loads, stream water

\section{INTRODUCTION}

Forests are bioindicators of environmental quality, particularly as regards atmospheric pollutants and climate changes. The high interannual variability of climate parameters means that forests used as biondicators must be regularly monitored over extended time periods (Innes 1998). In addition, because of the complexity of the mechanisms affecting the interaction between pollutants and trees, any assessment of the impact of pollution on forest ecosystems must involve a variety of environmental compartments: air, biota, water and soil. The movement of water (precipitation, runoff, soil solution, etc.) through the compartments of the ecosystem is of prime concern in the study of nutrient cycles and for quantitative measurements of fluxes at catchment scale (Likens 2001). Particularly in remote areas, atmospheric deposition loads, along with mineral weathering in the soil, are the main sources of nutrients and pollutants. An ecosystem with a high degree of ecological integrity is able to maintain and recycle nutrients through the decomposition and mineralisation of organic detritus. A long-term exposure to atmospheric contamination could affect the nutrient cycle, reducing the decomposition processes and the uptake of nutrients (Aber et al. 1989).
The alteration of nitrogen and sulphur cycles leads to acidification processes with the leaching of acidifying compounds (nitrate and sulphate) and the mobilization of toxic species such as aluminium (De Vries \& Breeuwsma 1987; Smith 1990).

Since 1987, the Water Research Insitute and the Regional Forest Board have been working together to establish a monitoring network in Lombardy for the evaluation of the relationships between atmospheric deposition and forest ecosystem responses. In particular our investigations were focused on high elevation catchments, especially sensitive to environmental perturbations due to high levels of precipitation, acid soils, and rapid hydrological flushing during runoff (Balestrini \& Tagliaferri 2001). Separate, interdisciplinary European projects (Azienda Regionale delle Foreste 1996, 1998) provided the framework for setting up innovative study methods. Exposed natural surfaces, such as vegetation and water, were used for determining dry deposition rates at a number of sites in the alpine and prealpine area. Additional research is currently being performed in Val Masino (SO) aimed at furthering our understanding of the effectiveness of the biological compartment in modifying the atmospheric element fluxes, and to investigate the role of nitrogen both as an acidifying

Paper prepared within the CONECOFOR programme, by the contract with the Ministry for Agriculture and Forestry Policy - National Forest Service, Italy. CONECOFOR is part of the Pan-European Level II Intensive Monitoring of Forest Ecosystem and is co-sponsored by the European Commission. 
Tab. 1. Specific research required at each monitoring level.

\begin{tabular}{lll}
\hline \multicolumn{1}{c}{ Level I } & \multicolumn{1}{c}{ Level II } & \multicolumn{1}{c}{ Level III } \\
\hline Site description & Accurate site description & Metereology \\
Tree basal diameter & Floristic survey & Biodiversity \\
Tree social class & Tree condition (60 indicators) & Additional pathological \\
Tree canopy closure & Deposition chemistry & analysis \\
Tree condition (20 indicators) & Foliar analysis & Soil solution chemistry \\
Soil description & Litterfall & Lichens \\
Soil analysis & Dendrology & Ozone monitoring \\
& + Level I & Air quality \\
& & + Level II \\
\hline
\end{tabular}

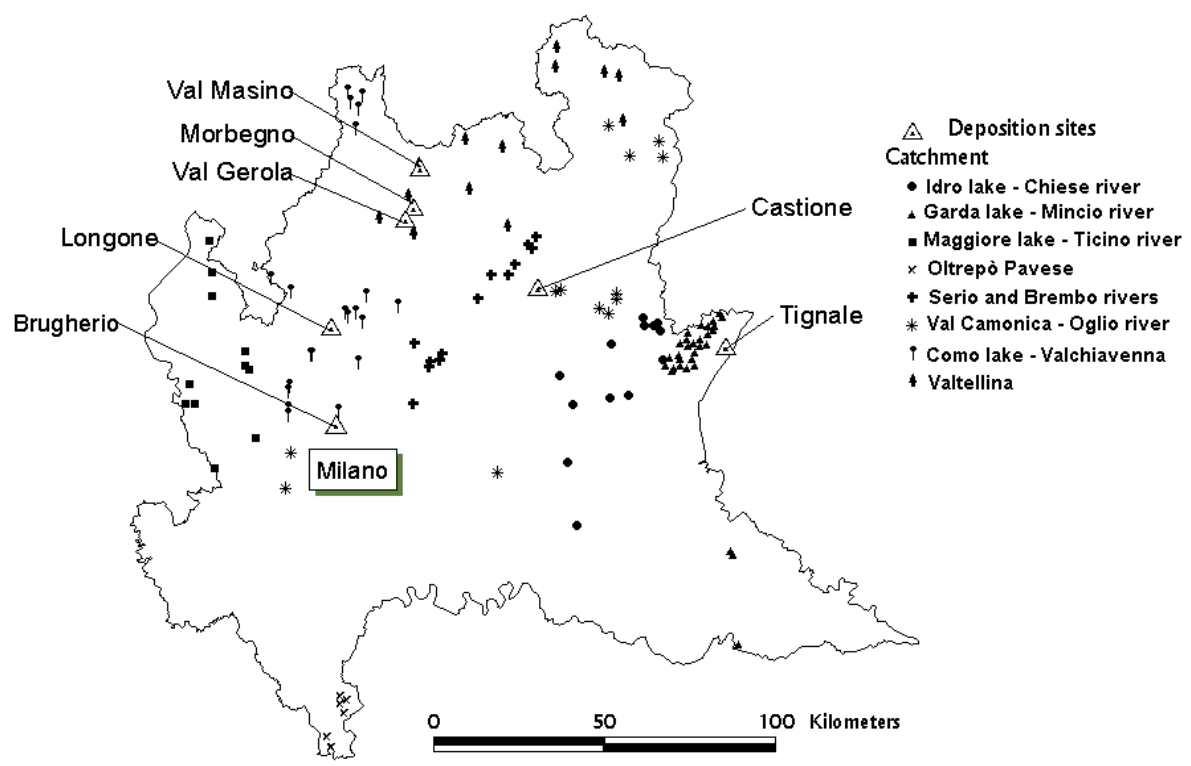

Fig. 1. Geographical location of the tree monitoring plots grouped for catchment and the atmospheric deposition monitoring sites.

element and as a nutrient. To estimate an input-output budget for the catchment, monitoring was extended to stream water and soil solution.

This paper reviews the main results of a five year research, and provides a general picture of the state of forest health over a wide area and focuses on some more detailed investigations described as case studies.

\section{MATERIAL AND METHODS}

\subsection{Monitoring network}

Since 1990, the Regional Forestry Board has been carrying out Level I forest condition monitoring on public forests in Lombardy, on 60 plots belonging to the regional $2 \times 2 \mathrm{~km}$ grid. This monitoring activity included crown condition assessment based on defoliation and discoloration, and a basic survey of the forest soil condition. In 1995 it was decided to extend the research to other ecosystem components (foliage, atmospheric depositions, air quality) and to refine the spatial variability of the sampling, leading to a new integrated survey system which included both Level I and Level II areas for extensive and intensive monitoring. At present, the monitoring system in Lombardy adheres closely to international protocols (ICP-Forest manuals) and is based on a pyramidal structure in which, as the number of analyses increases, the number of survey areas decreases. Monitoring is performed in 122 Level I permanent plots, 5 Level II plots and 1 Level III plot. The specific investigations required at each level are listed in table 1 .

\subsection{Tree monitoring}

The tree survey was carried out in a regional area defined by 8 catchments (Fig. 1 and Tab. 2). The most common forest species of the Lombardy Region, Ostrya carpinifolia Scop., Fagus sylvatica L., Quercus robur L., Larix decidua Mill., Picea abies Karst., Pinus silvestris L., were sampled.

The assessment of the trees was based on four components: the whole crown, the foliage, the ramification system and the stem; each indicator of tree condition was observed, described and quantified in relation to its nature, extent and any causal agents (Tab. 3). A quality control programme comprising learning, training, inter- 
Tab. 2. Number of monitoring plots and forest species monitored in each selected catchment in Lombardy.

\begin{tabular}{|c|c|c|}
\hline CATCHMENT & FOREST SPECIES & Plots $\left(n^{\circ}\right)$ \\
\hline A1) Lake Maggiore - River Ticino & F. sylvatica, P. silvestris, $Q$. robur & 11 \\
\hline A2) Oltrepò Pavese & O. carpinifolia, F. sylvatica & 6 \\
\hline A3) Lake Como - Chiavenna Valley & L. decidua, $P$. abies, $P$. silvestris, $O$. carpinifolia, $F$. sylvatica & 21 \\
\hline A4) Valtellina Valley & L. decidua, $P$. abies, $P$. silvestris & 15 \\
\hline A5) Serio and Brembo rivers & P. abies, $Q$. robur, O. carpinifolia, $F$. sylvatica & 13 \\
\hline A6) Val Camonica - Oglio River & P. abies, $Q$. robur, $F$. sylvatica & 13 \\
\hline A7) Lake Idro - River Chiese & P. abies, $Q$. robur, $O$. carpinifolia, $F$. sylvatica & 13 \\
\hline A8) Lake Garda - River Mincio & P. abies, $P$. silvestris, $O$. carpinifolia, $F$. sylvatica & 30 \\
\hline
\end{tabular}

Tab. 3. Indicators of tree condition used at each monitoring level.

\begin{tabular}{llc}
\hline & INDICATORS & Plots \\
\hline Crown & Leaf loss: type, pattern, amount, cause, location & Level I \\
& Trasparency: type, pattern, amount & Level I \\
& Flowering: frequency & Level I \\
& Fruiting: frequency & Level II \\
& Dieback: type, location, frequency, causes & Level II \\
& Leaf retention: upper part, central part, lower part & Level II \\
& Premature leaf fall: frequency, causes & Level II \\
& Discoloration: type, frequency, location/crown, location/branch, location/leaf, cause & Level I \\
Foliage & Malformation: type, frequency, intensity, cause & Level I \\
& Damage: type, frequency, cause & Level I \\
& Size: type, extent, cause & Level I \\
& Type & Level I \\
Ramification & Level I \\
& Regeneration: frequency, density, vigour & Level II \\
& Proleptic shoots: frequency, vigour & Level II \\
& Lichens & Level II \\
& Mosses & Level II \\
& Phanerogamae & Level II \\
& Damage: type, age, frequency, location, cause & Level I \\
Regeneration: frequency, density, vigour & Level II \\
& Dead branches: frequency & Level II \\
& Lichens & Level II \\
& Mosses & Level II \\
& Phanerogamae & Level II \\
\hline
\end{tabular}

calibration and control phases was implemented during each annual campaign. Further details are given in the ESPERIME report (Azienda Regionale delle Foreste 1998).

\subsection{Monitoring of atmospheric input}

Atmospheric deposition samples were collected at six sampling stations in the Region of Lombardy, chosen to represent the various geographical conditions and expected pollution levels of the area (Fig. 1). The topographical and geological characteristics of the sampling sites are shown in table 4 . The sites are described in detail in Balestrini et al. (2000) and in Balestrini \& Tagliaferri (2001).

Wet and dry atmospheric depositions were collected by automated samplers (MTX Italia, Quarto Inferiore, Bologna) incorporating modified dry deposition sampling devices, called DAS (dry Deposition on Aqueous Surface), which use water as the collecting surface. For a detailed description of the sampler see Tartari et al. (1995).

Samples were collected at Morbegno and Longone over three years, from July 1995 to June 1998. Sam- pling in Castione and Tignale was from July 1995 to June 1997. Wet and dry deposition sampling at Val Masino began in April 1997 and ended in November 1999, with interruptions during the winter snow period, generally from November to April. Wet samples were collected weekly, dry samples every two weeks.

Rainfall and throughfall were collected at the Val Masino and Val Gerola sites from June 1994 to May 1999; at the Val Masino site the monitoring is still going on.

From June 1994 to May 1996 each throughfall study area was a $50 \times 50 \mathrm{~m}^{2}$ plot where 15 throughfall polyethylene samplers (9 $\mathrm{cm}$ diameter) were placed $10-15 \mathrm{~m}$ from each other, avoiding clearings and tracks. To harmonise our methods with international procedures (ICPForest 1998), in June 1996 we reduced the number of throughfall samplers to 9 and located them systematically inside a $30 \times 30 \mathrm{~m}^{2}$ subplot. Each new collector is composed of an $18 \mathrm{~cm}$ polyethylene funnel fitted on a 5 1 polyethylene bucket. Bulk precipitation was collected by a $33.5 \mathrm{~cm}$ polyethylene funnel fitted on a 151 polyethylene bucket installed in a clearing near each throughfall site. Both bulk precipitation and throughfall 
Tab. 4. Topographical and geological features of the sampling stations.

\begin{tabular}{lccccc}
\hline Sites & $\begin{array}{c}\text { Altitude } \\
(\mathrm{m} \text { a.s.l. })\end{array}$ & Latitude North & Longitude East & $\begin{array}{c}\text { Rainfall } \\
(\mathrm{mm})\end{array}$ & Geology \\
\hline Longone & 370 & $45^{\circ} 49^{\prime}$ & $09^{\circ} 16^{\prime}$ & 1045 & Marl, marly limestone \\
Tignale & 600 & $45^{\circ} 45^{\prime}$ & $10^{\circ} 44^{\prime}$ & 1043 & Chert, marl, limestone \\
Castione & 920 & $45^{\circ} 55^{\prime}$ & $10^{\circ} 02^{\prime}$ & 1622 & Dolomite \\
Morbegno & 260 & $46^{\circ} 08^{\prime}$ & $09^{\circ} 34^{\prime}$ & 1043 & Paragneiss \\
Val Masino & 1190 & $46^{\circ} 14^{\prime}$ & $09^{\circ} 35^{\prime}$ & 1681 & Granodiorite \\
Val Gerola & 1490 & $46^{\circ} 06^{\prime}$ & $09^{\circ} 32^{\prime}$ & 1545 & Gneiss \\
\hline
\end{tabular}

Tab. 5. Analytical methods.

\begin{tabular}{lcc}
\hline VARIABLES & METHODS & REFERENCES \\
\hline $\mathrm{pH}$ & Potentiometry & -- \\
Conductivity & Conductometry & -- \\
Alkalinity & Two-endpoint potentiometric titration & A.P.H.A. 1971 \\
Ammonium & Spectrophotometry Indophenol-blu method & Fresenius et al. 1988 \\
Nitrate & Ion chromatography & Camusso \& Polesello 2000a \\
Sulphate & Ion chromatography & Camusso \& Polesello 2000a \\
Chloride & Ion chromatography & Camusso \& Polesello 2000a \\
Calcium & Ion chromatography & Camusso \& Polesello 2000b \\
Magnesium & Ion chromatography & Camusso \& Polesello 2000b \\
Potassium & Ion chromatography & Camusso \& Polesello 2000b \\
Sodium & Ion chromatography & Camusso \& Polesello 2000b \\
Total nitrogen & Acid-alkaline peroxodisulphate oxidation and U.V. spectrophotometry & Valderrama 1981 \\
Total phosphorous & Acid-alkaline peroxodisulphate oxidation and UV spectrophotometry & Valderrama 1981 \\
\hline
\end{tabular}

samplers were equipped with plastic nets to prevent birds from alighting. During the winter months (December-March/April) snow samples were collected in bigger buckets $(21 \mathrm{~cm}$ diameter for throughfall and 39.4 $\mathrm{cm}$ diameter for the bulk). The sampling frequency was weekly.

\subsection{Monitoring of stream water}

Stream water samples were collected in the central section of the catchment at the Val Masino site, from May 1997 to the present. Samples were collected about weekly from the onset of snowpack runoff to September and about monthly for the remainder of the year, except during the December-April period when the stream was frozen. The depth of the water is measured by a hydrometric gauge placed at the sampling site.

A dilution tracer method was used to measure the discharge of the river Masino. In shallow rocky streams or rough channels carrying highly turbulent flows, the dilution technique provides an alternative to the mechanical method, as it can minimise the difficulties linked to the river bed morphology and flow features (White 1978; Elder \& Kattelmann 1990). The flow was measured under four different hydrological conditions within a 30-80 $\mathrm{cm}$ range of water depth. The results made it possible to describe the water depth-discharge relationship, used to estimate the discharge for any measured value of water depth.

\subsection{Analytical procedures}

Aliquots of water samples, including those containing dry depositions, were analysed for the following variables: $\mathrm{pH}$, conductivity, alkalinity, nitrate, chloride, sulphate, ammonium, calcium, magnesium, sodium, potassium, total nitrogen, total phosphorous. Analytical methods and equipment used are reported in table 5. For detailed descriptions of the analytical procedures see Balestrini et al. (2000).

\section{RESULTS AND DISCUSSION}

\subsection{Tree condition}

The results are shown using the usual categorical system based on injury classes. Each class is defined by crown transparency, assessed in 5\% steps and grouped into 5 classes: none, slight, moderate, severe, dead. Injuries were classified according to their dependence on known or unknown agents. This last category included all damage which was not due to evident causes observable during the sampling; these were therefore injuries produced by various environmental stresses.

Table 6 describes the condition of trees in Lombardy assessed during 1999. The total injury (TI), obtained by summing up all the injury classes $(1+2+3+4)$, and the apparent injury (AI), obtained by summing up the three upper classes $(2+3+4)$, are indicated for each species. Each class is defined by the explained plus unexplained crown transparency.

More than $80 \%$ of the monitored trees were classified in classes 1 to 4 , with $43.6 \%$ included in classes 2 4. Quercus robur was the forest species characterised by the highest percentage of both AI (68\%) and TI (96.3\%) followed by Fagus sylvatica. Larix decidua showed the smallest percentage of damage. During 1999, 16\% of 
Tab. 6. Injury classes for species during 1999. AI = apparent injury, TI = total injury.

\begin{tabular}{|c|c|c|c|c|c|c|c|c|c|c|c|c|c|c|}
\hline & \multicolumn{2}{|c|}{$\begin{array}{c}0 \\
\text { (none) }\end{array}$} & \multicolumn{2}{|c|}{$\begin{array}{c}1 \\
\text { (slight) }\end{array}$} & \multicolumn{2}{|c|}{$\begin{array}{c}2 \\
\text { (moderate) } \\
\end{array}$} & \multicolumn{2}{|c|}{$\begin{array}{c}3 \\
\text { (severe) }\end{array}$} & \multicolumn{2}{|c|}{$\begin{array}{c}4 \\
(\mathrm{dead})\end{array}$} & \multicolumn{2}{|c|}{$\begin{array}{c}\mathrm{AI} \\
(2+3+4) \\
\end{array}$} & \multicolumn{2}{|c|}{$\begin{array}{c}\text { TI } \\
(1+2+3+4)\end{array}$} \\
\hline & $\mathrm{n}$ & $\%$ & $\mathrm{n}$ & $\%$ & $\mathrm{n}$ & $\%$ & $\mathrm{n}$ & $\%$ & $\mathrm{n}$ & $\%$ & $\mathrm{n}$ & $\%$ & $\mathrm{n}$ & $\%$ \\
\hline Q. robur & 14 & 3.7 & 106 & 28.3 & 135 & 36.0 & 114 & 30.4 & 6 & 1.6 & 255 & 68.0 & 361 & 96.3 \\
\hline F. sylvatica & 59 & 10.4 & 217 & 38.2 & 201 & 35.4 & 91 & 16.0 & - & - & 292 & 51.4 & 509 & 89.6 \\
\hline O. carpinifolia & 93 & 16.1 & 241 & 41.7 & 162 & 28.0 & 80 & 13.8 & 2 & 0.4 & 244 & 42.2 & 485 & 83.9 \\
\hline P. silvestris & 99 & 18.9 & 191 & 36.4 & 206 & 39.2 & 29 & 5.5 & - & - & 235 & 44.8 & 426 & 81.1 \\
\hline P. abies & 136 & 27.5 & 155 & 31.3 & 168 & 33.9 & 36 & 7.3 & - & - & 204 & 41.2 & 359 & 72.5 \\
\hline L. decidua & 188 & 35.6 & 233 & 44.1 & 100 & 18.9 & 7 & 1.3 & - & - & 107 & 20.3 & 340 & 64.4 \\
\hline Total & 589 & 19.2 & 1143 & 37.2 & 972 & 31.7 & 357 & 11.7 & 8 & 0.3 & 1337 & 43.6 & 2480 & 80.8 \\
\hline
\end{tabular}

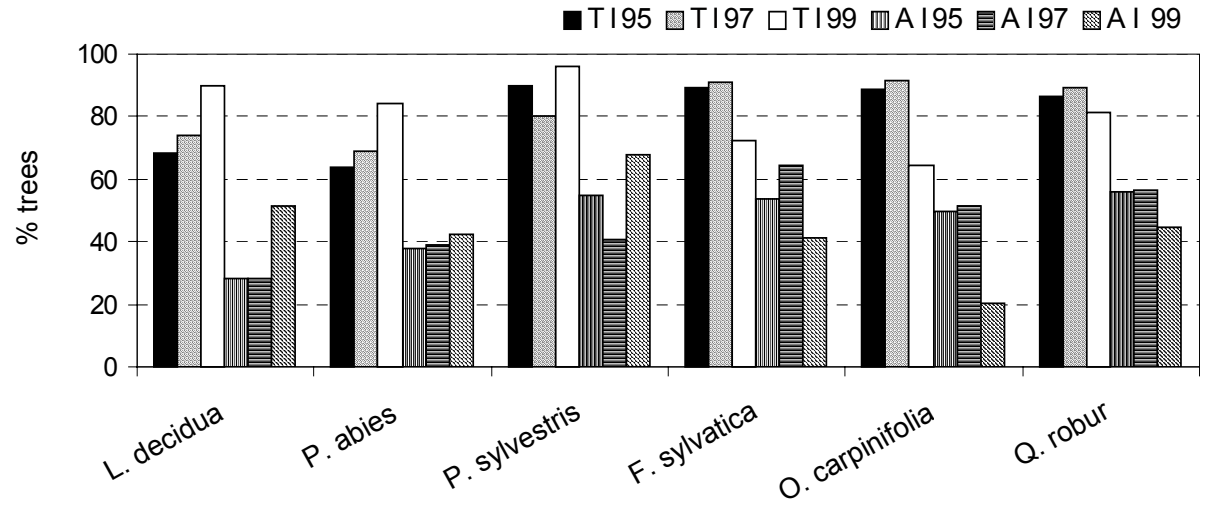

Fig. 2. Annual trend of total injury (TI) and apparent injury (AI) evaluated in 1995, 1997 and 1999 for each monitored species.

the trees exhibited damage symptoms due to known agents, while $69.7 \%$ of the trees showed unexplained injuries, with $33.2 \%$ of these affected by moderate/severe damage (classes $2+3+4)$.

From a geographic point of view, the results of the 1999 monitoring indicated that there was no injury due to known agents in the Valtellina catchments, while in contrast the highest percentages of unexplained injury were measured in the eastern basins of lakes Garda and Idro.

Figure 2 shows the annual trend of total injury and apparent injury for each monitored species. The total transparency (explained plus unexplained) assessed for L. decidua and A. abies showed a gradually increasing trend from 1995 to 1999 , while a reduction of damage was seen in $F$. sylvatica and $O$. carpinifolia during the last year of monitoring. The trend for $P$. sylvestris and $Q$. robur was variable. In most cases, the observed transparency could not be explained by known agents. The total transparency level assessed for $O$. carpinifolia was wholly due to unknown causes. The contribution of explained transparency was of importance only for $P$. sylvestris in 1999 and for Q. robur in 1995 and 1996.

The total unexplained transparency levels assessed during 1995-1999 in each forest catchment are shown in figure 3 . The increasing trend of damage in the whole regional area is clear, and is particularly high for A1 and A6 (Lake Maggiore- River Ticino and Val CamonicaRiver Oglio). The exceptions were catchments A3 and
A4 (Lake Como - Val Chiavenna and Valtellina Valley) where the tree conditions did not appear to change. Altitude was the only geographical feature showing a relationship with the unexplained transparency. The areas of medium elevation were characterised by a higher transparency class, in particular altitudes of 400-500 $\mathrm{m}$ a.s.1 for $O$. carpinifolia, 500-600 m a.s.l. for $F$. sylvatica, $P$. abies and P. sylvestris, and 600-700 $\mathrm{m}$ a.s.l. for $O$. carpinifolia. This result could be related to the recent findings on ozone height distribution in Lombardy, which showed higher concentrations in the prealpine area (Regione Lombardia \& Fondazione Lombardia Ambiente 2000).

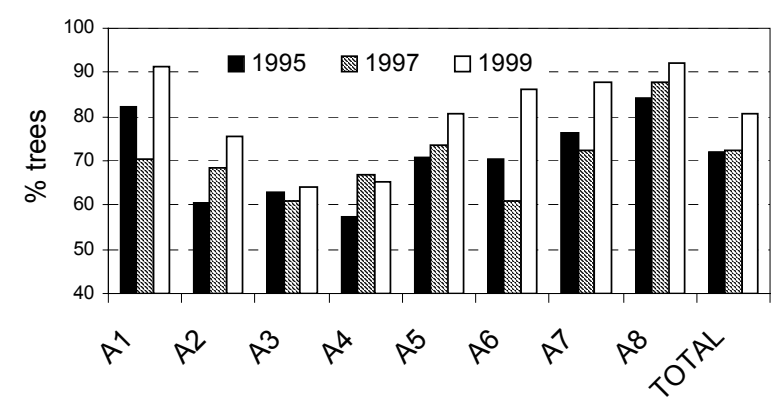

Fig. 3. Transparency level assessed in each catchment during the three-year monitoring period. 
Tab. 7. Volume-weighted mean values of concentration ( $\mu$ eq $1^{-1}$ ) of throughfall (TF) and bulk precipitation (BP) samples collected at Val Gerola and Val Masino.

\begin{tabular}{|c|c|c|c|c|c|c|c|c|c|c|c|c|c|c|c|c|c|c|}
\hline & \multicolumn{2}{|c|}{$\mathrm{H}^{+}$} & \multicolumn{2}{|c|}{$\mathrm{N}-\mathrm{NH}_{4}{ }^{+}$} & \multicolumn{2}{|c|}{$\mathrm{N}-\mathrm{NO}_{3}{ }^{-}$} & \multicolumn{2}{|c|}{$\mathrm{SO}_{4}=$} & \multicolumn{2}{|c|}{$\mathrm{Cl}^{-}$} & \multicolumn{2}{|c|}{$\mathrm{Ca}^{2+}$} & \multicolumn{2}{|c|}{$\mathrm{Mg}^{2+}$} & \multicolumn{2}{|c|}{$\mathrm{Na}^{+}$} & \multicolumn{2}{|c|}{$\mathrm{K}^{+}$} \\
\hline & $\mathrm{BP}$ & $\mathrm{TF}$ & $\mathrm{BP}$ & $\mathrm{TF}$ & $\mathrm{BP}$ & $\mathrm{TF}$ & $\mathrm{BP}$ & $\mathrm{TF}$ & $\mathrm{BP}$ & $\mathrm{TF}$ & $\mathrm{BP}$ & $\mathrm{TF}$ & $\mathrm{BP}$ & $\mathrm{TF}$ & $\mathrm{BP}$ & $\mathrm{TF}$ & $\mathrm{BP}$ & $\mathrm{TF}$ \\
\hline \multicolumn{19}{|l|}{ Val Gerola } \\
\hline $94-95$ & 12 & 12 & 20 & 16 & 23 & 57 & 31 & 53 & 7 & 22 & 22 & 69 & 4 & 20 & 7 & 15 & 2 & 65 \\
\hline $95-96$ & 13 & 14 & 28 & 12 & 26 & 47 & 34 & 48 & 9 & 22 & 26 & 59 & 9 & 20 & 10 & 13 & 3 & 78 \\
\hline $96-97$ & 8 & 6 & 25 & 17 & 22 & 33 & 28 & 33 & 7 & 12 & 35 & 56 & 6 & 13 & 7 & 10 & 3 & 37 \\
\hline $97-98$ & 11 & 9 & 24 & 24 & 25 & 52 & 30 & 38 & 7 & 15 & 30 & 48 & 4 & 17 & 6 & 11 & 2 & 47 \\
\hline $98-99$ & 10 & 9 & 24 & 23 & 25 & 45 & 30 & 39 & 8 & 15 & 37 & 59 & 5 & 14 & 9 & 12 & 2 & 38 \\
\hline Mean (94-99) & 11 & 10 & 24 & 18 & 24 & 47 & 31 & 42 & 8 & 17 & 30 & 58 & 6 & 17 & 8 & 12 & 2 & 53 \\
\hline \multicolumn{19}{|l|}{ Val Masino } \\
\hline $94-95$ & 10 & 5 & 23 & 13 & 23 & 27 & 33 & 40 & 9 & 13 & 23 & 36 & 4 & 12 & 7 & 10 & 2 & 41 \\
\hline $95-96$ & 8 & 7 & 25 & 18 & 24 & 36 & 29 & 41 & 6 & 13 & 31 & 53 & 6 & 16 & 7 & 9 & 2 & 45 \\
\hline $96-97$ & 10 & 6 & 27 & 15 & 23 & 24 & 32 & 29 & 5 & 8 & 22 & 40 & 4 & 11 & 5 & 6 & 2 & 31 \\
\hline $97-98$ & 15 & 6 & 23 & 19 & 23 & 35 & 29 & 32 & 8 & 11 & 19 & 42 & 3 & 12 & 7 & 8 & 2 & 35 \\
\hline $98-99$ & 8 & 4 & 23 & 21 & 23 & 32 & 28 & 34 & 6 & 11 & 35 & 55 & 5 & 13 & 8 & 13 & 2 & 37 \\
\hline Mean (94-99) & 10 & 6 & 24 & 17 & 23 & 31 & 30 & 35 & 7 & 11 & 26 & 45 & 4 & 13 & 7 & 9 & 2 & 38 \\
\hline
\end{tabular}

\subsection{Open field and throughfall deposition chemistry: a comparison between Val Masino and Val Gerola}

As part of an interdisciplinary project (BallarinDenti et al. 1998) aimed at evaluating the interactions between environmental stress and forest decline in Lombardy, we investigated the throughfall chemistry of two forest stands (Val Masino and Val Gerola) known to have different levels of damage.

The study areas, Val Masino and Val Gerola, are situated in two lateral valleys on the north and south sides of the main valley, Valtellina (SO) (Fig. 1). Although they are at a short distance (about $20 \mathrm{~km}$ ) from each other, the morphology of the areas is different: the Val Masino site, on the north side, is located in a typical glacial valley surrounded by an amphitheatre of mountains rising to 3500 metres; Val Gerola, on the south side, is in a fluvial valley characterised by steep slopes and 2500 metre peaks. Since 1994, tree condition has been assessed by observing the whole crown, the foliage, the ramification system and the stem. Symptoms of defoliation and yellowing are more frequent at Val Gerola than at Val Masino, where the trees have a healthier appearance (Azienda Regionale delle Foreste 1998). Air quality $\left(\mathrm{O}_{3}, \mathrm{NO}_{\mathrm{x}}, \mathrm{SO}_{\mathrm{x}}, \mathrm{VOC}\right)$ was monitored during four summer seasons (1994-1997) using automatic and passive sampling devices (Gerosa et al. 1999). Measured values were comparable to those reported for unpolluted sites, with the exception of ozone, which showed different ambient concentrations at the two sites: at Val Gerola only, the measured levels were often above the phytotoxicity threshold.

Precipitation and throughfall chemistry data were used to compare these two forest stands, with an evaluation of the filtering capacity of the canopies for dry deposition and the extent of foliar leaching. Table 7 shows the concentrations measured at the study site during 1994-1999.

The Mann-Whitney U test was used to compare ion concentrations from each site. The results indicated that, for all variables analysed in bulk precipitation samples, values did not differ significantly between sites, except for $\mathrm{Mg}^{2+}$ for which $\mathrm{p}$ was $<0.05$. As regards throughfall concentrations, the two sites differed in measured values of $\mathrm{H}^{+}, \mathrm{N}^{-\mathrm{NO}_{3}}{ }^{-}, \mathrm{Cl}^{-}, \mathrm{Na}^{+}, \mathrm{K}^{+}, \mathrm{DOC}$ and weak acids, w.a. (estimated as cations minus anions).

The significance of the variations between ion concentrations in bulk precipitation and throughfall, tested using the Sign test, was high $(p<0.0001)$ for all the chemicals analysed with the exception of $\mathrm{H}^{+}$, at $\mathrm{Val}$ Gerola, and N-NH${ }_{4}{ }^{+}$, at Val Masino. These results demonstrate the high degree of filtering effected by spruce canopies, leading to an ionic enrichment of $48 \%$ and $36 \%$ in the throughfall of Val Gerola and Val Masino, respectively. The $\mathrm{K}^{+}$enrichment was the highest, with a 19-fold increase at Val Masino and a 27-fold increase at Val Gerola. $\mathrm{Ca}^{2+}$ and $\mathrm{Mg}^{2+}$ also showed a 2-3 fold increment in throughfall at both sites. $\mathrm{SO}_{4}{ }^{2-}$ concentration in throughfall was 27 and $14 \%$ higher than in the bulk, at Val Gerola and Val Masino, respectively. $\mathrm{N}^{-\mathrm{NO}_{3}}{ }^{-}$ was almost double at Val Gerola, where it was the predominant anion; at Val Masino it was slightly above (26\%). N-NH ${ }_{4}^{+}$concentration decreased in throughfall by about $25-29 \%$ at both stations, along with $\mathrm{H}^{+}$, which showed a reduction of $10 \%$ and $40 \%$ at Val Gerola and Val Masino respectively.

Table 8 shows the bulk and throughfall fluxes measured during the study period at the two sites. The interannual variations were generally relatively small and related to the amount of precipitation. The measured bulk deposition fluxes of $\mathrm{SO}_{4}{ }^{2-}$ were close to the central values of the range reported for Italian forest sites in the national network CONECOFOR (Mosello et al. 1999). Reduced nitrogen deposition in our area was similar to the higher values of the reported range. In general, on the basis of the results of a survey of 65 European forests, the $\mathrm{N}$ loads measured in our sites are intermediate for $\mathrm{N}$ deposition level $\left(10-25 \mathrm{~kg} \mathrm{ha}^{-1} \mathrm{y}^{-1}\right)$. At this level symptoms of $\mathrm{N}$ saturation could occur (Dise \& Wright 1995). 
Tab. 8. Atmospheric deposition fluxes (meq $\mathrm{m}^{-2} \mathrm{y}^{-1}$ ) measured at the study sites during the five-year monitoring period. w.a.: weak acids (estimated as cations minus anions).

\begin{tabular}{|c|c|c|c|c|c|c|c|c|c|c|c|c|c|c|c|c|c|c|c|c|}
\hline & \multicolumn{2}{|c|}{$\mathrm{H}^{+}$} & \multicolumn{2}{|c|}{$\mathrm{N}-\mathrm{NH}_{4}{ }^{+}$} & \multicolumn{2}{|c|}{$\mathrm{N}-\mathrm{NO}_{3}{ }^{-}$} & \multicolumn{2}{|c|}{$\mathrm{SO}_{4}{ }^{=}$} & \multicolumn{2}{|c|}{$\mathrm{Cl}^{-}$} & \multicolumn{2}{|c|}{$\mathrm{Ca}^{2+}$} & \multicolumn{2}{|c|}{$\mathrm{Mg}^{2+}$} & \multicolumn{2}{|c|}{$\mathrm{Na}^{+}$} & \multicolumn{2}{|c|}{$\mathrm{K}^{+}$} & \multicolumn{2}{|c|}{ w.a. } \\
\hline & $\mathrm{BP}$ & TF & $\mathrm{BP}$ & $\mathrm{TF}$ & BP & $\mathrm{TF}$ & $\mathrm{BP}$ & $\mathrm{TF}$ & $\mathrm{BP}$ & $\mathrm{TF}$ & $\mathrm{BP}$ & $\mathrm{TF}$ & BP & $\mathrm{TF}$ & $\mathrm{BP}$ & $\mathrm{TF}$ & $\mathrm{BP}$ & $\mathrm{TF}$ & BP & $\mathrm{TF}$ \\
\hline$A$ & & & & & & & & & & & & & & & & & & & & \\
\hline $6 / 94-5 / 95$ & 19.0 & 12.9 & 31.2 & 16.6 & 35.4 & 60.0 & 48.6 & 55.6 & 10.9 & 22.9 & 34.2 & 72.6 & 5.8 & 21.5 & 10.4 & 16.1 & 2.5 & 68.4 & 2.7 & 65.5 \\
\hline $6 / 95-5 / 96$ & 17.2 & 13.1 & 37.2 & 11.3 & 34.3 & 43.9 & 44.5 & 44.6 & 11.6 & 20.5 & 33.9 & 55.5 & 12.4 & 18.3 & 12.7 & 12.0 & 3.3 & 72.4 & 13.6 & 71.3 \\
\hline $6 / 96-5 / 97$ & 15.7 & 10.5 & 47.1 & 27.6 & 41.2 & 54.2 & 51.3 & 54.3 & 12.3 & 19.5 & 64.7 & 93.1 & 10.3 & 21.5 & 13.5 & 16.9 & 5.7 & 61.5 & 38.7 & 83.4 \\
\hline 8 & 16.2 & 10.9 & 35.7 & 28.1 & 36.5 & 61.4 & 44.4 & 45.1 & 10.6 & 18.0 & 34.0 & 55.9 & 6.3 & 19.7 & 9.0 & 12.6 & 3.1 & 54.7 & 14.6 & 55.6 \\
\hline $6 / 98-5 / 99$ & 16.0 & 11.1 & 38.0 & 26.4 & 38.7 & 52.8 & 47.1 & 45.7 & 12.7 & 17.3 & 55.7 & 69.2 & 7.9 & 16.0 & 13.9 & 13.5 & 3.6 & 44.1 & 23.9 & 57.2 \\
\hline Mean & 16.8 & 11.7 & 37.8 & 22.0 & 37.2 & 54.5 & 47.2 & 49.1 & 11.6 & 19.6 & 44.5 & 69.3 & 8.5 & 19.4 & 11.9 & 14.2 & 3.6 & 60.2 & 18.7 & 66.6 \\
\hline d.s & 1.3 & 1.2 & 5.8 & 7.6 & 2.8 & 6.9 & 2.9 & 5.4 & 0.9 & 2.2 & 14.7 & 15.4 & 2.8 & 2.3 & 2.1 & 2.2 & 1.2 & 11.3 & 13.5 & 11.3 \\
\hline . & & & & & & & & & & & & & & & & & & & & \\
\hline $6 / 9$ & 16.7 & 6.2 & o & 16.2 & 39.3 & 33.0 & 58.0 & 47 & 15.3 & 15.3 & 40.7 & 2 & 6.3 & 14.1 & 12.3 & 12.1 & 3.9 & 49.1 & 9.6 & 42.2 \\
\hline $6 / 95$ & 11.7 & 6.5 & 36.5 & 17.3 & 34.6 & 34.2 & 41.9 & 38.8 & 8.8 & 12.3 & 44.7 & 50.7 & 8.1 & 15.3 & 9.6 & 8.6 & 2.7 & 42.6 & 12.9 & 32.6 \\
\hline $6 / 96-5 / 97$ & 20.4 & 10.2 & 54.7 & 25.5 & 46.3 & 40.7 & 64.4 & 50.6 & 10.7 & 13.5 & 67.9 & 67.9 & 9.1 & 19.2 & 11.0 & 10.6 & 4.8 & 53.7 & 33.0 & 73.7 \\
\hline $6 / 97-5 / 98$ & 24.7 & 7.7 & 38.0 & 26.0 & 38.5 & 48.2 & 47.9 & 43.9 & 12.9 & 14.4 & 32.6 & 57.9 & 5.4 & 16.6 & 11.9 & 10.7 & 2.7 & 47.4 & 12.1 & 53.0 \\
\hline $6 / 98-5 / 99$ & 11.9 & 4.5 & 35.4 & 24.9 & 35.4 & 38.1 & 44.0 & 40.6 & 9.5 & 13.7 & 55.6 & 65.8 & 7.5 & 16.2 & 12.7 & 15.5 & 3.6 & 44.5 & 21.9 & 62.3 \\
\hline Mean & 17.1 & 7.0 & 40.9 & 22.0 & 38.8 & 38.8 & 51.2 & 44.3 & 11.4 & 13.9 & 48.3 & 57.1 & 7.3 & 16.3 & 11.5 & 11.5 & 3.5 & 47.5 & 17.9 & 52.8 \\
\hline d.s. & 5.6 & 2.1 & 7.9 & 4.8 & 4.6 & 6.1 & 9.6 & 4.9 & 2.6 & 1.1 & 13.7 & 10.3 & 1.4 & 1.9 & 1.2 & 2.6 & 0.9 & 4.3 & 9.6 & 16.2 \\
\hline
\end{tabular}

The canopy budget model, developed by Ulrich (1983), was applied to estimate leaching and the contribution of dry deposition in throughfall fluxes at the study sites (Balestrini et al. 2001). It is worth noting that, in this model, the fraction of compounds not collected by the bulk sampler is indicated as "dry deposition". At Val Gerola the contributions of $\mathrm{N}^{-\mathrm{NO}_{3}}{ }^{-}$and $\mathrm{SO}_{4}{ }^{2-}$ dry flux to the total deposition were $32 \%$ and $4 \%$, respectively. The dry deposition of $\left(\mathrm{H}^{+}+\mathrm{N}-\mathrm{NH}_{4}^{+}\right)$to the total deposition accounted for $24 \%$ of the bulk deposition. Regarding the base cations, the dry contribution from $\mathrm{K}^{+}$and $\mathrm{Mg}^{2+}$ was negligible, while it was $15 \%$ for $\mathrm{Ca}^{2+}$. At Val Masino the contribution of the dry component to the total deposition is not detectable by the model.

Since the dry deposition depends on meteorological parameters and on the features of the receiving surface, the observed differences could be ascribed to the morphological and meteoclimatic characteristics of the two studied areas. A detailed analysis of meteorological parameters carried out at the two valleys showed differences in wind speed and prevailing wind direction (Azienda Regionale delle Foreste 1998). The Val Gerola site, which is higher and has a more open valley, is more exposed to the air masses coming from the plain and the pre-alpine belt where urbanisation is greatest, whereas Val Masino is subject only to breezes of local origin or deriving from the Valtellina Valley bottom. A study on air quality in the same areas supports this hypothesis, with higher ozone levels measured in Val Gerola than in Val Masino. This difference was ascribed to the different orographic profiles, the different atmospheric circulation, and the presence of ozone transported from outside the valley and not only of local origin (Gerosa et al. 1999).

Canopy leaching computed for $\mathrm{Ca}^{2+}, \mathrm{K}^{+}$, weak acids and $\mathrm{Cl}^{-}$was considerably higher in Val Gerola than in
Val Masino; this indirectly suggests tree tissue damage. Natural factors such as tree age, as well as anthropogenic stress factors such as air pollution, can lead to a modification of the epicuticular wax structure of conifer needles and increase the leaching of nutrients. A study of the leaf alterations of one year-old Norway spruce needles from Val Gerola revealed injury symptoms, including pigmentation on the adaxial leaf surface. Optical and electron microscopy showed that the injury was associated with chlorophyll loss and deposits of calcium oxalate (Violini 1998; Azienda Regionale delle Foreste 1998). Some of the observed symptoms were similar to those described in literature for forest species exposed to high levels of ozone (Turunen \& Huttunen 1990; Skelly et al. 1999).

\subsection{Wet and dry deposition fluxes in alpine and prealpine areas}

The atmospheric deposition data available for Italy are not uniformly distributed throughout the whole territory and do not provide a firm basis for interpreting spatial variations, particularly in areas with complex orography. Furthermore, the available data on the dry deposition fraction are not sufficient for a correct evaluation of the extent of total atmospheric deposition.

The aims of the investigation reported here were to examine the chemical composition and to calculate the fluxes of wet and dry atmospheric deposition at five sites within a $140 \times 70 \mathrm{~km}$ area of northern Italy. The area includes subalpine and alpine zones with extensive forested areas and is flanked by two major Italian lakes.

Table 9 shows the percentages of dry deposition fluxes on the total at the study sites. The contribution of the dry component to the total deposition is considerable, particularly for acidifying compounds. The dry deposition of $\mathrm{SO}_{4}{ }^{2-}$ accounted for $14-50 \%$ of the total deposition; the deposition of $\mathrm{N}_{-} \mathrm{NO}_{3}{ }^{-}$and $\mathrm{N}-\mathrm{NH}_{4}{ }^{+}$were 
Tab. 9. Total atmospheric deposition fluxes (meq $\left.\mathrm{m}^{-2} \mathrm{y}^{-1}\right)$ and dry flux contributions (\%) to the total (wet + dry).

\begin{tabular}{|c|c|c|c|c|c|c|c|c|c|c|c|}
\hline & & $\mathrm{H}^{+}$ & $\mathrm{HCO}_{3}^{-}$ & $\mathrm{N}-\mathrm{NH}_{4}^{+}$ & $\mathrm{N}-\mathrm{NO}_{3}^{-}$ & $\mathrm{SO}_{4}{ }^{=}$ & $\mathrm{Cl}^{-}$ & $\mathrm{Ca}^{2+}$ & $\mathrm{Mg}^{2+}$ & $\mathrm{Na}^{+}$ & $\mathrm{K}^{+}$ \\
\hline LONGONE & $\begin{array}{l}\text { total } \\
\% \text { dry }\end{array}$ & $\begin{array}{c}22.0 \\
3.8\end{array}$ & $\begin{array}{l}41.5 \\
48.0\end{array}$ & $\begin{array}{c}109.6 \\
21.2\end{array}$ & $\begin{array}{l}78.5 \\
22.8\end{array}$ & $\begin{array}{l}103.0 \\
32.9\end{array}$ & $\begin{array}{l}22.6 \\
28.8\end{array}$ & $\begin{array}{c}115.5 \\
45.9\end{array}$ & $\begin{array}{l}18.9 \\
47.1\end{array}$ & $\begin{array}{l}20.9 \\
25.8\end{array}$ & $\begin{array}{c}5.5 \\
58.2\end{array}$ \\
\hline CASTIONE & $\begin{array}{l}\text { total } \\
\% \text { dry }\end{array}$ & $\begin{array}{l}13.0 \\
1.2\end{array}$ & $\begin{array}{l}82.0 \\
55.4\end{array}$ & $\begin{array}{c}103.3 \\
33.2\end{array}$ & $\begin{array}{l}62.0 \\
23.9\end{array}$ & $\begin{array}{l}75.4 \\
24.7\end{array}$ & $\begin{array}{l}19.3 \\
35.8\end{array}$ & $\begin{array}{c}114.8 \\
40.6\end{array}$ & $\begin{array}{l}17.7 \\
46.3\end{array}$ & $\begin{array}{l}18.2 \\
29.7\end{array}$ & $\begin{array}{c}6.7 \\
67.2\end{array}$ \\
\hline TIGNALE & $\begin{array}{l}\text { total } \\
\% \text { dry }\end{array}$ & $\begin{array}{l}9.8 \\
8.3\end{array}$ & $\begin{array}{l}72.7 \\
62.0\end{array}$ & $\begin{array}{l}79.4 \\
30.7\end{array}$ & $\begin{array}{l}52.9 \\
30.6\end{array}$ & $\begin{array}{l}75.3 \\
38.6\end{array}$ & $\begin{array}{l}15.5 \\
33.5\end{array}$ & $\begin{array}{c}126.0 \\
54.7\end{array}$ & $\begin{array}{l}19.2 \\
57.3\end{array}$ & $\begin{array}{l}17.8 \\
29.8\end{array}$ & $\begin{array}{c}4.8 \\
66.7\end{array}$ \\
\hline MORBEGNO & $\begin{array}{l}\text { total } \\
\% \text { dry }\end{array}$ & $\begin{array}{c}16.1 \\
9.1\end{array}$ & $\begin{array}{l}40.3 \\
81.6\end{array}$ & $\begin{array}{l}67.2 \\
36.9\end{array}$ & $\begin{array}{l}40.4 \\
23.8\end{array}$ & $\begin{array}{l}75.1 \\
50.5\end{array}$ & $\begin{array}{l}11.1 \\
39.6\end{array}$ & $\begin{array}{l}81.5 \\
62.8\end{array}$ & $\begin{array}{l}14.0 \\
64.3\end{array}$ & $\begin{array}{l}11.4 \\
39.5\end{array}$ & $\begin{array}{c}5.1 \\
74.5\end{array}$ \\
\hline VAL MASINO & $\begin{array}{l}\text { total* } \\
\% \text { dry }\end{array}$ & $\begin{array}{c}17.1 \\
3.3\end{array}$ & $\begin{array}{l}13.9 \\
78.8\end{array}$ & $\begin{array}{l}40.9 \\
13.9\end{array}$ & $\begin{array}{l}38.8 \\
15.0\end{array}$ & $\begin{array}{l}51.2 \\
14.2\end{array}$ & $\begin{array}{l}11.4 \\
23.2\end{array}$ & $\begin{array}{l}48.3 \\
46.8\end{array}$ & $\begin{array}{c}7.3 \\
27.4\end{array}$ & $\begin{array}{l}11.5 \\
26.8\end{array}$ & $\begin{array}{c}3.5 \\
58.3\end{array}$ \\
\hline
\end{tabular}

in the range $15-31 \%$ and $14-37 \%$ of the total, respectively. The lowest dry values were measured at Val Masino, which is a high site, not exposed to air masses rising from the main valley floor. Pluriannual studies on throughfall atmospheric deposition have documented the remoteness of this valley (Balestrini et al. 2001).

The contribution of dry flux $\mathrm{SO}_{4}{ }^{2-}$ to the total deposition varied considerably between the stations, constituting half the total in Morbegno, 39\% in Tignale, 33\% in Longone and $25 \%$ in Castione. At Morbegno, a town of about 10,000 inhabitants at the beginning of the Valtellina Valley, the highest dry fluxes of $\mathrm{SO}_{4}{ }^{2-}$ were measured in winter, suggesting that a local source of $\mathrm{S}$ is domestic heating systems, most of which use oil, though some use coal. Nitrate dry percentages are more homogeneous at these four stations, with a mean of 25.3 and a standard deviation of 3.5. Reduced nitrogen was the prevalent chemical form in both dry and wet depositions, comprising $58-63 \%$ and $56-72 \%$ respectively of total deposited inorganic nitrogen. The higher $\mathrm{N}^{-} \mathrm{NH}_{4}{ }^{+}$ dry contributions found at Morbegno and Castione could be explained by agriculture, which is the main anthropic activity in these areas. Figure 4 shows the total deposition fluxes (wet plus dry) of potential acidity at the five study sites compared with fluxes recorded at Brugherio, an urban industrial site close to Milan (Tartari et al. 1995). Milan is the largest urban area within the Po Valley. For this reason, comparison of our findings with those at Brugherio $(10 \mathrm{~km}$ north-east of the centre of Milan and within the large industrial belt extending north and east of the city) can provide some indication of the effects of long-range pollution in the study area. For Val Masino, yearly fluxes were estimated from a bulk sampler over the period 1994-1999. The bulk fluxes at the latter site are probably representative of the total atmospheric fluxes there, since the contribution of gaseous and aerosol components is not very significant, as indicated by the relatively small dry loads recorded.

Figure 4 suggests a relationship between pollutant loads and distance from Milan. Brugherio had the highest $\mathrm{H}^{+}$load, followed by Longone, about $50 \mathrm{~km}$ from Milan. Morbegno and Castione are both about $100 \mathrm{~km}$ from Milan, but Castione has a wetter climate and is more exposed to ammonia from agricultural activity. Tignale, at the eastern extremity of the study area, is distant from Milan (about $150 \mathrm{~km}$ ), but influenced by two other large urban centres, Verona and Brescia, both about fifty kilometres away. Val Masino is, as noted, at high altitude, about $150 \mathrm{~km}$ from Milan and characterised by the lowest deposition rates.

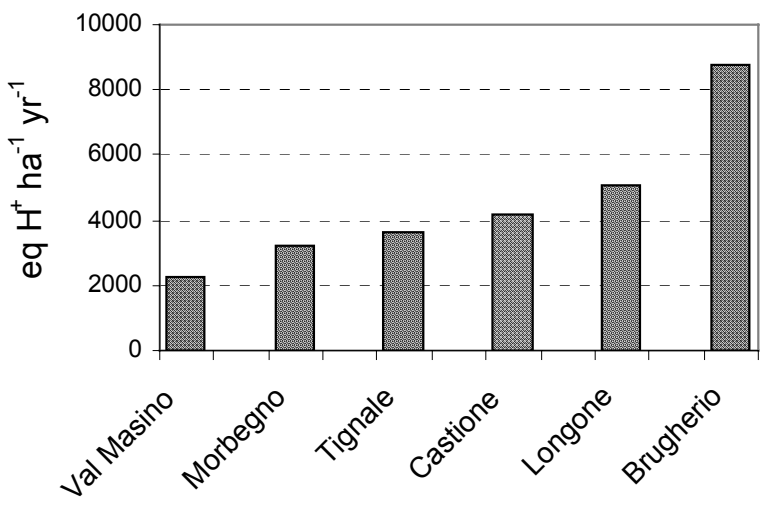

Fig. 4. The average annual potential acid deposition (eq $\mathrm{ha}^{-1}$ $\left.\mathrm{y}^{-1}\right)$ to the study sites.

Comparison of the total atmospheric fluxes with the critical loads of nitrogen and sulphur estimated for forest soils in Italy on a $50 \mathrm{~km}$ basis (Posch et al. 1997) indicates that the critical load for nitrogen has been exceeded at all stations. At three sites the maximum critical load (CLN) of nitrogen as an acidifier was exceeded by about $6 \mathrm{~kg} \mathrm{ha}^{-1} \mathrm{y}^{-1}$ at Longone and Tignale, and $2 \mathrm{~kg}$ $\mathrm{ha}^{-1} \mathrm{y}^{-1}$ at Castione, while the maximum critical load for nitrogen as a nutrient was exceeded at all sites. This finding has important environmental implications, as more than $85 \%$ of the forest ecosystems in Lombardy are in alpine and subalpine areas. The co-occurence of acidification and nitrogen eutrophication in forest ecosystems increases the potential for damage. Acidification leads to increased leaching of basic cations from the soil, whereas increased nitrogen leads to imbalance of the nutrients $\mathrm{P}, \mathrm{K}^{+}, \mathrm{Ca}^{2+}$ and $\mathrm{Mg}^{2+}$, and increases the potential of attacks by parasites, diseases and insects 
(Erisman et al. 1998). These effects are likely to be particularly serious and worrying at Longone and Castione, where the nitrogen loads were about 4 times higher than the critical values, corresponding to an excess of 20.7 and $17.2 \mathrm{~kg} \mathrm{ha}^{-1} \mathrm{y}^{-1}$ respectively.

\subsection{Input-output budget in Val Masino catchment}

In trying to extend our understanding of the processes affecting the nitrogen and sulphur biogeochemical cycles, we focused many of our researches on the Val Masino area.

A catchment of interest was defined on a 1: 25,000scale topographic map, and comprised the upper basin of the River Masino where the monitoring plots are located. The exact area of the catchment and the percentages of land cover surfaces (aquatic areas, rock, grazing ground and pasture, meadow, bog and marsh, urban area, coniferous forest, deciduous forest, mixed forest) were measured using a 1:10,000 scale geoenvironmental map (Tab. 10).

Tab. 10. Main land cover features of the experimental catchment.

\begin{tabular}{lc}
\hline Meadow & $38 \%$ \\
Rock & $37 \%$ \\
Grazing ground/pasture & $8.8 \%$ \\
Mixed forest & $7.9 \%$ \\
Coniferous forest & $5.2 \%$ \\
Aquatic area & $2.3 \%$ \\
Deciduous forest & $0.6 \%$ \\
Bog and marsh & $0.1 \%$ \\
Urban area & $0.04 \%$ \\
Catchment area & $25.2 \mathrm{~km}^{2}$ \\
\hline
\end{tabular}

The budget was calculated with atmospheric deposition as input and the streamwater load as output. The throughfall flux and the open field flux were ascribed respectively to the forested surface and to the rest of the catchment. The streamwater export is considered to be the only route of water and element loss at the Val Masino site.

The water flux measured in the catchment from $\mathrm{Au}$ gust 1997 to July 1998 is given in table 11 .

Tab. 11. Val Masino: water fluxes ( $\mathrm{mm})$ for the experimental catchment during the period August 1997 - July 1998.

\begin{tabular}{lc}
\hline Bulk precipitation & 1743 \\
Canopy throughfall & 1436 \\
Discharge & 1283 \\
Evapotranspiration & 439 \\
\hline
\end{tabular}

The discrepancy between the evapotranspiration, calculated using the Turc formula (Turc 1954), and the value obtained from the difference between precipitation and discharge is very small $(21 \mathrm{~mm})$, and might be the result of inaccurate discharge measurements, since the readings of water height were not continuous.
Table 12 shows the input and output fluxes for the main chemical species. Normally, input and output fluxes of chloride are expected to balance over the long term, as this ion is relatively conservative and is not affected by biogeochemical processes. Although the data given here represent only one year of measurements, the chloride budget of the Val Masino catchment is quite well balanced: input exceeded output by only $13 \%$. The small retention of chloride recorded may be due to an acceptable error in budget calculation, confirming the efficacy of the criteria applied to calculate the budget, and suggests that other water fluxes are insignificant. It is worth noting that significant retention of chloride has also been observed in some catchments in North America, Scandinavia and the UK (Reynolds et al. 1997; Forsius et al. 1995; Schindler 1986), so that it is possible that the retention observed in Val Masino is a real phenomenon.

$\mathrm{SO}_{4}{ }^{2-}$ output exceeds the input from throughfall, indicating that the ecosystem currently acts as a source rather than a sink. Net sulphur losses have been reported for many forested catchments of Europe and North America (Rochelle et al. 1987; Hornbeck et al. 1997, Feger et al. 1990). Sulphur loss could be caused by inaccurate dry deposition measurements, weathering of Sbearing minerals, net mineralisation and desorption (Mitchell et al. 1992; Houle \& Carignan 1995). The dry sulphate deposition on the catchment appears to be low to account for the imbalance between input and output, and lithogenic sulphur sources can be disregarded, due to the siliceous nature of the geological substrate. The excess sulphate output from the catchment could be attributed to desorption of previously stored sulphate in the context of decreasing atmospheric S deposition in northern Italy (Mosello et al. 1999; Regione Lombardia 1999).

As regards nitrogen compounds, ammonium was retained nearly completely, while $91 \%$ of nitrate was lost from the basin. The uptake of ammonium by vegetation reduced its atmospheric input by more than $45 \%$ even before its deposition on the soil. During transport to the stream, other processes, such as adsorption to the soil components and root and microbial uptake, further decreased the flux toward the stream water. The nitrate export measured in the catchment, $5 \mathrm{~kg} \mathrm{ha}^{-1} \mathrm{y}^{-1}$, exceeds the leaching value reported for natural coniferous stands of $1 \mathrm{~kg} \mathrm{ha}^{-1} \mathrm{y}^{-1}$ (Gundersen \& Rasmussen 1990). The budget calculated for the inorganic nitrogen (as sum of $\mathrm{N}-\mathrm{NO}_{3}{ }^{-}$and $\mathrm{N}-\mathrm{NH}_{4}{ }^{+}$) showed that $50 \%$ of the input was retained. This finding was in agreement with with the results of an estimate, based on more than 139 forest sites in Europe, which indicates that about half of the inorganic nitrogen in throughfall is lost to runoff, and the rest is stored in the catchment (Dise et al. 1998).

The approach proposed by Traen \& Stoddard (1995) was applied to evaluate the nitrogen saturation status of the Val Masino catchment. Figure 5 shows the nitrate 
Tab. 12. Total atmospheric input, streamflow output and budget $\left(\mathrm{kg} \mathrm{ha}^{-1} \mathrm{y}^{-1}\right)$ for the Val Masino catchment from August 1997 to July 1998.

\begin{tabular}{lcccccccccc}
\hline & $\mathrm{N}^{-N_{4}}{ }^{+}$ & $\mathrm{N}_{-N O}{ }^{-}$ & $\mathrm{SO}_{4}{ }^{=}$ & $\mathrm{Cl}^{-}$ & $\mathrm{Ca}^{2+}$ & $\mathrm{Mg}^{2+}$ & $\mathrm{K}^{+}$ & $\mathrm{Na}^{+}$ & $\mathrm{TN}$ & $\mathrm{TP}$ \\
\hline input & 5.1 & 5.6 & 24.4 & 4.7 & 7.7 & 0.9 & 1.7 & 1.5 & 14.5 & 0.3 \\
output & 0.3 & 5.1 & 38.2 & 4.1 & 41.4 & 2.9 & 7.7 & 8.6 & 5.8 & 0.0 \\
in - out & 4.8 & 0.5 & -13.8 & 0.6 & -33.7 & -2.1 & -6.0 & -7.1 & 8.6 & 0.3 \\
\hline
\end{tabular}

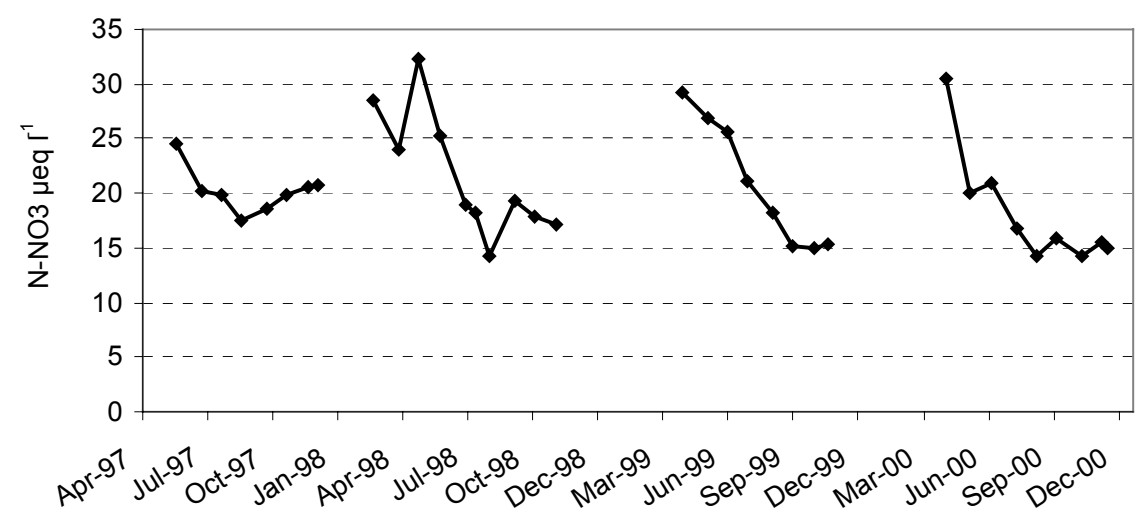

Fig. 5. Nitrate concentration ( $\mu \mathrm{eq} 1^{-1}$ ) of streamwater measured during the period May 1997-November 2000.

monthly trend measured during 1997-2000. Nitrate concentration varied from 14 to $32 \mu \mathrm{eq} \mathrm{l}^{-1}$ with maximum values in April, during the snowmelt, and minimum values in August. Although variations of nitrate in the water are clearly controlled by seasonality, the basin is classified as stage 2 , i.e. in which $\mathrm{N}$ availability exceeds the biological demand. The method applied assumes that nitrate in the stream water depends mainly on the biological and chemical processes occurring in the soil system, and neglects the importance of the prevailing flow pathways of water in different soils. In the case of a non-uniform soil structure, the runoff is mainly generated by a preferential flow through macropores that does not favour a long interaction between precipitation and soil matrix (Flury et al. 1994; Creed \& Band 1998). In this case, N-leaching is mainly related to the concentration of nitrate in precipitation and snowmelt rather than to the internal N-status of the soil. This might be the case in the Val Masino catchment, which is characterised by steep rocky slopes $\left(20^{\circ}\right)$ and a heterogeneous soil structure. Water residence and contact with the soil matrix may not be sufficient for the nitrate present in the runoff to be immobilised by the microbial community. Ongoing research on soil solution composition in the study area indicates a very low level of inorganic nitrogen compounds at 30 and $50 \mathrm{~cm}$ soil depth, suggesting an N-limitation condition of the catchment (Balestrini, unpublished data).

\section{CONCLUSIONS}

The six year research carried out in Lombardy originated as an evaluation of the direct influence of rainwater on forest trees. The present evolution of this ac- tivity is largely in the direction of an ecosystemic evaluation of the factors controlling the driving mechanisms in different environmental compartments.

As regards our short-term objectives, we have succeeded in establishing methodologies both in tree condition assessment and wet and dry atmospheric deposition measurements. The latter application made it possible to compare total atmospheric loads (not only the wet component) with the critical loads, highlighting a condition of nitrogen exceedance which extended over the entire regional territory. This exceedance is of prime concern in the prealpine belt, which is more exposed to the Po Valley.

The promising results obtained for Val Masino and Val Gerola supported the identification of a potential link between environmental determinants of disturbance and forest health. However, further investigation is required at both sites to distinguish more clearly the roles of the different factors.

The ongoing activity at Val Masino, based on a catchment approach, promises to provide a better understanding of nutrient cycles in alpine forest ecosystems. The preliminary results indicate the importance of the chemical analysis of both soil water and stream water in evaluating the biological and chemical processes occurring in the basin.

The considerable amount of information collected so far has emphasised the complexity of the interactions between stress factors and the biological response of the forest ecosystem, but the time period covered is not yet long enough for trends to be detected and causal relationships identified.

Prospects for further studies may be: 
- long-term monitoring to detect the trends in chemical composition of atmospheric depositions in remote alpine areas, such as Val Masino;

- comparison of the dry deposition rates estimated by net throughfall with those measured by the DAS collector at rural or suburban sites, where the dry contribution is considerable, to enhance our understanding of the role of trees in retaining gaseous pollutants/nutrients;

- fine-tuning of the input-output budget by more precise measurement of the hydrological balance in the Val Masino catchment;

- assessment of the suitability of the Traen and Stoddard (1995) nitrogen saturation model in alpine catchments characterised by specific climatic and geopedological features.

\section{ACKNOWLEDGMENTS}

The authors are grateful to Dr. M. Prina (Water Research Institute), Dr. A. Isernia (Water Research Institute), Dr. A. Gubertini (Regional Forestry Board of Lombardy) and Dr. A. Cozzi (Linnea Ambiente, S.r.l.) for their help in making available the data in this paper.

\section{REFERENCES}

A.P.H.A., A.W.W.A., W.P.C.F. 1971. Standard methods for examination of water and wastewater. Am. Publ. Health Ass., New York: 874 pp.

Aber, J.D., K.J. Nadelhoffer, P. Steudler \& J.M. Melillo. 1989. Nitrogen Saturation in Northern Forest Ecosystems: Excess nitrogen from fossil feul combustion may stress the biosphere. BioScience, 39: 378-386.

Azienda Regionale delle Foreste. 1996. Atmospheric contamination effects on forest ecosystem. Report CE 93.60 IT.00.80 (Reg. CEE 2157/92): 192 pp.

Azienda Regionale delle Foreste 1998. Soil experiments to improve the knowledge of the atmospheric pollution. Report CE 94.60 IT.00.90 (Reg.CEE 2157/92): 303 pp.

Balestrini, R. \& A. Tagliaferri. 2001. Atmospheric deposition and canopy exchange processes in alpine forest ecosystems (Northern Italy). Atmospheric Environment, 35/36: 6421-6433.

Balestrini, R., L. Galli \& G. Tartari. 2000. Wet and dry atmospheric deposition at prealpine sites in Northern Italy. Atmospheric Environment, 34: 1455-1470.

Ballarin-Denti, A., S.M. Cocucci \& F. Sartori. 1998. Monitoraggio delle foreste sotto stress ambientale. Fondazione Lombardia per l'Ambiente, Milano. 425 pp.

Camusso, M. \& S. Polesello. 2000a. Determinazione di anioni (cloruro, nitrato, solfato, bromuro, fluoruro, fosfato e nitrito) mediante cromatografia ionica. Notiziario dei metodi analitici, IRSA-CNR, febbraio 2000: 1-8.

Camusso, M. \& S. Polesello. 2000b. Determinazione di cationi (sodio, ammonio, potassio, magnesio e calcio) mediante cromatografia ionica. Notiziario dei metodi analitici, IRSA-CNR, febbraio 2000: 8-14.

Creed, I.F. \& L.E. Band. 1998. Export of nitrogen from catchments within a temperate forest: evidence of unifying mechanisms regulated by variable source area dynamics. Water Resources Research; 34: 3105-3120.

De Vries, W. \& A. Breeuwsma. 1987. The relation between soil acidification and element cycling. Water, Air and Soil Pollution, 35: 293-310.
Dise, N.B. \& R.F. Wright. 1995. Nitrogen leaching from European forests in relation to nitrogen deposition. Forest Ecology and Management, 71: 153-161.

Elder, K. \& R. Kattelmann. 1990. Refinements in dilution gauging for mountain streams. Hydrology in Mountainous Regions. I-Hydrological Measurements; the Water Cycle. Proceedings of two Lausanne Symposia, August 1990. IAHS Publ. $\mathrm{N}^{\circ} 193$.

Erisman, J.W., K. van der Hoek, J.R. Wisniewski \& J. Wisniewski. 1998. Nitrogen, the Confer-N-s (Special issue). Environmental Pollution, 103: 3-12.

Feger, K.H., G. Brahmer \& H.W. Zottl. 1990. Element budget of two contrasting catchments in the Black Forest (Federal Republic of Germany). Journal of Hydrology, 116: 85-99.

Flury, M., H. Fluhler, W.A. Jury \& J. Leuenberger. 1994. Susceptibility of soils to preferential flow of water: A field study. Water Resources Research, 30: 1945-1954.

Forsius, M., S. Kleemola, M. Starr \& T. Ruoho-Airola. 1995. Ion mass budgets for small forested catchments in Finland. Water, Air, and Soil Pollution, 79: 19-38.

Fresenius, W., K.E. Quentin \& W. Schneider (Eds). 1988. Water Analysis. Springer Verlag, Berlin: 804 pp.

Gerosa, G., F. Spinazzi \& A. Ballarin Denti. 1999. Tropospheric ozone in alpine forest sites: air quality monitoring and statistical data analysis. Water Air and Soil Pollution, 116: 345-350.

Gundersen, P \& L. Rasmussen. 1990. Nitrification in forest soils: effects from nitrogen deposition on soil acidification and aluminum release. Reviews of Environmental Contamination and Toxicology, 113: 1-39.

Hornbeck, J.W., S.W. Bailey, D.C. Buso \& J.B. Shanley. 1997. Streamwater chemistry and nutrient budgets for forested watersheds in New England: variability and management implications. Forest Ecology and Management, 93: 73-89.

Houle, D. \& R. Carignan. 1995. Role of SO4 adsorption and desorption in the long-term $\mathrm{S}$ budget of a coniferous catchment on the Canadian Shield. Biogeochemistry, 28: 161-182.

ICP-Forest.1998. Manual on methods and criteria for harmonised sampling, assessment, monitoring and analysis of the effects of air pollution on forests. Programme Coordinating Centre Federal research Centre for Forestry and Forest Product (Ed.), Hamburg.

Innes, J.L. 1998. Measuring environmental change. In: Peterson D.L. \& V.T. Parker (Eds). Ecological Scale. Columbia University Press, N.Y.:429-457.

Likens, G. E. 2001. Biogeochemistry, the watersheed approach: some uses and limitations. Marine Freshwater Research, 52: 5-12.

Mitchell, J.M, M.K. Burke \& J.P. Shepard. 1992. Seasonal and spatial patterns of $\mathrm{S}, \mathrm{Ca}$, and $\mathrm{N}$ dynamics of a Northern Hardwood forest ecosystem. Biogeochemistry, 17: 165-189.

Mosello, R., A. Marchetto, A. Boggero, M.C. Brizzio, G.A. Tartari \& M. Rogora. 1999. Pluriannual evolution of the hydrochemistry of two alpine lakes (Lake Paione Inferiore and lake Paione Superiore, Ossola Valley) in relation to atmospheric loads. J. Limnol., 58: 42-48.

Posch, M., J.-P. Hettelingh, P.A.M. de Smet \& R.J. Downing (Eds). 1997. Calculation and Mapping of Critical Thresholds in Europe. CCE Status Report RIVM Bilthoven, Netherlands. Rep. No. 259101007: 97-102.

Regione Lombardia \& Fondazione Lombardia Ambiente. 2000. Piano Regionale per la Qualità dell'Aria. FLA CDRom.

Regione Lombardia. 1999. Rapporto sullo stato dell'ambiente in Lombardia-1999. Direzione Generale Tutela Ambientale: 87-127.

Reynolds, B., D. Fowler, R.I. Smith \& J.R. Hall. 1997. Atmospheric inputs and catchment solute fluxes for major 
ions in five Welsh upland catchments. J. Hydrol., 194: 305-329.

Rochelle, B.P., M.R. Church \& M.B. David. 1987. Sulfur retention at intensively studied sites in the U.S.A. and Canada. Water, Air, and Soil Pollution, 33: 73-83.

Schindler, D.W. 1986. The significance of in-lake production of alkalinity. Water, Air, and Soil Pollution, 30: 931- 954.

Skelly, J.M., J.L. Innes, J.E. Savage, K.R. Snyder, D. Vanderheyden, J. Zhang \& M.J. Sanz. 1999. Observation and confirmation of foliar ozone nsymptomps of native plant species of Switzerland and Southern Spain. Water Air and Soil Pollution, 116: 227-234.

Smith, W.H. 1990. Air pollution and forests. Springer-Verlag, New York: 611 pp.

Tartari, G., A. Consuma, R. Balestrini, S. Valsecchi \& M. Camusso. 1995. Total atmospheric deposition measurements using an innovative dry deposition sampler. Life Chemistry Reports, 13: 159-175.

Traaen, T.S. \& J.L. Stoddard. 1995. An Assessment of Nitrogen Leaching from Watersheds included in ICP on Waters. NIVA Report No. 86001:1-35.
Turc, L. 1954. Calcul du bilan de l'eau: Evaluation en function des precipitations et des temperatures. IAHS-Publications, 38: 188-200.

Turunen, M. \& S. Huttunen. 1990. A review of the response of epicuticular wax of conifer needles to air pollution. Journal of Environmental Quality, 19: 35-45.

Ulrich, B. \& J. Pankrath. 1983. Interaction of forest canopies with atmospheric constituents: $\mathrm{SO}_{2}$, alkali cations and chloride. In: Reidel Publ. Co. (Eds), Effects of accumulation of air pollutants in forest ecosystems. Dordrecht Netherlands: 33-55.

Valderrama, J.C. 1981. The simultaneous analysis of total nitrogen and total phosphorous in natural waters. Marine Chemistry, 10: 109-122.

Violini, G. 1998. Il danno rilevato a livello istologico e ultrastrutturale. In: Fondazione Lombardia per l'Ambiente (Ed.). Monitoraggio delle foreste sotto stress ambientale. Milano: 312-315

Withe, K.E. 1978. Dilution Methods. In: Herschy R.W. (Ed), Hydrometry. John Wiley \& Sons: 111-148. 